\title{
Innovations in vascular and endovascular surgery in Brazil: a data analysis study
}

\author{
Inovações em cirurgia vascular e endovascular no Brasil: uma análise de dados
}

Heriberto Brito de Oliveira', Sergio Quilici Belczak', Eymard Francisco Brito de Oliveira'

\begin{abstract}
Background: Innovations in vascular and endovascular surgery have important social and economic repercussions. Most endovascular devices used in Brazil are imported and, therefore, particularly expensive. Objective: To conduct a retrospective analysis of patent and regulatory approval data for newly developed vascular and endovascular devices, based on the number of patents registered at the Brazilian National Industrial Property Institute (INPI) and the number of products approved by the National Health Surveillance Agency (ANVISA) over recent years. Methods: This retrospective study involved electronic searches of the INPI (www.inpi.gov.br) and ANVISA websites (www.anvisa.gov.br), for patents registered and products approved between January 1997 and December 2012. Results: The keywords used for the search ("catheter(s)," "stent(s)," "graft(s)," and "wound dressing(s)") returned a total of 701 new patents registered during the period studied. Thirty-four percent $(n=237)$ of these were patents for wound dressings, while the remaining 66\% ( $n=464)$ were for devices used in endovascular surgery. Only $7.8 \%(n=268)$ of the 3433 products approved by ANVISA during the period analyzed were produced in Brazil. Conclusions: The social and economic importance of innovations in health care highlights the need to monitor them, to register them and to support their production, in view of the need to develop local alternatives to imported health care technology.
\end{abstract}

Keywords: endovascular procedures; vascular surgical procedures; technological innovation; patents; product approval.

\begin{abstract}
Resumo
Contexto: As inovações em cirurgia vascular e endovascular são responsáveis por grande impacto econômico e importância social. Em sua grande maioria, os materiais são importados, onerando ainda mais o seu custo. Objetivo: Realizar uma análise retrospectiva dos Registros de Patentes e da liberação para utilização dos produtos do segmento da cirurgia vascular e endovascular, de acordo com o número de patentes depositadas no Instituto Nacional de Propriedade Industrial (INPI) e as publicações deferidas autorizando utilização dos produtos pela Agência Nacional de Vigilância Sanitária (ANVISA), nos últimos anos. Método: Estudo retrospectivo, no período de janeiro de 1997 a dezembro de 2012, por meio de pesquisa de dados eletrônicos no site do INPI e dados referentes à liberação para utilização de produtos médicos no site da ANVISA. Resultados: Encontraram-se 701 registros de novas patentes referentes a inovações tecnológicas na área de cirurgia vascular e endovascular, com os termos pesquisados ['cateter(es)', 'stent(s)', 'endoprótese(s)']. Destes, 34\% (n=237) foram referentes a registros de patentes de novos curativos e 66\% $(n=464)$, de materiais utilizáveis em cirurgia endovascular. Dentre os 3.433 novos registros liberados pela ANVISA, aproximadamente 7,8\% $(n=268)$ são de produtos fabricados no Brasil. Conclusões: A importância econômica e social das inovações em saúde demonstra o quão importante é a sua monitorização, o seu registro e o apoio para sua produção, com a visão da necessidade do desenvolvimento de soluções nacionais para este mercado.
\end{abstract}

Palavras-chave: cirurgia endovascular; cirurgia vascular; inovação tecnológica; patentes; aprovação de produtos. 


\section{INTRODUCTION}

When Gordon Earl Moore, a co-founder of Intel ${ }^{\circledR}$, spoke of technological development and costs in 1965, he postulated that computer processing power would double every 18 months, without a corresponding increase in their cost. This hypothesis proved to be accurate, and became known as Moore's Law. In contrast, technological innovations in medicine have resulted in increasing worldwide health care costs which, unlike what would be expected if Moore's Law also applied to medicine, have not significantly decreased with technological development. In fact, only $0.5 \%$ of effective innovations cost less than the technology they were developed to replace. ${ }^{1,2}$

Today, $17.9 \%$ of the gross domestic product of the United States of America (USA) goes toward health care, as compared to only $4 \%$ in 1950 ; the health sector has gained increasing importance in the economy, and 25 years from now it may absorb up to $30 \%$ of United States' GDP. ${ }^{1-3}$ In the USA, approximately US\$ 12 billion is spent every year on endovascular devices. Ninety percent of aortic aneurysms in the USA are treated using endovascular surgery. It is estimated that US\$3.96 billion, in Brazil, and US\$260 billion worldwide is spent on endovascular devices every year. Meditronik ${ }^{\circledR}$ and Gore $^{\circledR}$ in the USA, Cook ${ }^{\circledR}$ in Australia and Braile Biomédica $^{\circledR}$ in Brazil $^{4-6}$ are the largest of the 17 major manufacturers of endovascular products in the world.

Technological advances in the form of new medications, more sophisticated diagnostic procedures (which allow for the early discovery of previously underdiagnosed conditions), and more effective surgical materials and techniques are the main reasons for worldwide increases in health care spending. ${ }^{7-11}$

Therefore, in recent years, innovations and patents in medicine have had increasing social and economic repercussions, as has development of endovascular devices such as catheters, stents, grafts and wound dressings. Although the duration of surgery and recovery times associated with endovascular procedures have decreased, the cost of endovascular devices has sharply increased, which is primarily due to the fact that such products are usually imported. This situation creates a distortion of sorts, in that medical knowledge and experience appear to have become less relevant than technological innovation, surgical devices and civil responsibility. ${ }^{1-11}$

In light of these observations, the objective of this study was to conduct a retrospective analysis of patent and regulatory approval data for newly developed vascular and endovascular devices, based on the number of patents registered at the Brazilian
National Industrial Property Institute (INPI) and of products approved by the National Health Surveillance Agency (ANVISA) over recent years.

\section{METHOD}

This was a retrospective study conducted on data recorded between January 1997 and December 2012. Data on technological developments for endovascular surgery were retrieved through electronic searches on the INPI website (www.inpi. gov.br), and information on the approval of new technology was acquired from the ANVISA website (www.anvisa.gov.br). The following keywords were used for the electronic search: "stent(s)," "graft(s)," "catheter(s)" and "wound dressing(s)." Any patent entries identified by these keywords, but which did not describe a vascular/endovascular device were discarded from the sample. The term "guide wire" was excluded from the search because it resulted in an insignificant number of patents and product approvals.

The search results were used to analyze changes in the number of patent registries and product approvals over the course of the period studied. The percentage of newly patented products that were also approved for use by ANVISA was also analyzed.

\section{RESULTS}

The electronic search revealed that 701 new patents for vascular and endovascular devices were registered with the INPI during the period studied (Table 1). Thirty-four percent $(n=237)$ of these were patents for wound dressings, $16 \%$ were for stents, $5 \%$ for grafts and $45 \%$ for catheters. Most of the patents found were registered between 2005 and 2011 (Figure 1).

The search also revealed that ANVISA approved the use of a total of 3433 new endovascular products over the period studied (Table 2). Approximately $11.9 \%$ of these $(n=410)$ were new types of wound dressings, $6 \%$ were stents, $1 \%$ were grafts, and $81 \%$ were catheters. The number of products approved by ANVISA remained stable over the course of the period studied (Figure 2).

Table 1. Number of patents registered with the INPI between 1997 and 2012.

\begin{tabular}{lc}
\hline \multicolumn{1}{c}{ Search terms } & N \\
\hline Stent(s) & 113 \\
Graft(s) & 36 \\
Catheter(s) & 315 \\
Wound dressing(s) & 237 \\
Total & 701 \\
\hline
\end{tabular}


Only $7.8 \%(n=268)$ of the 3433 products approved by ANVISA during the period analyzed were produced in Brazil (Table 2). When the results retrieved using each search term were analyzed separately, $4.3 \%(\mathrm{n}=8)$ of the entries were found to refer to stents, $26.08 \%(\mathrm{n}=12)$ to grafts, $4.8 \%(\mathrm{n}=135)$ to catheters and $27.5 \%(\mathrm{n}=113)$ to wound dressings.

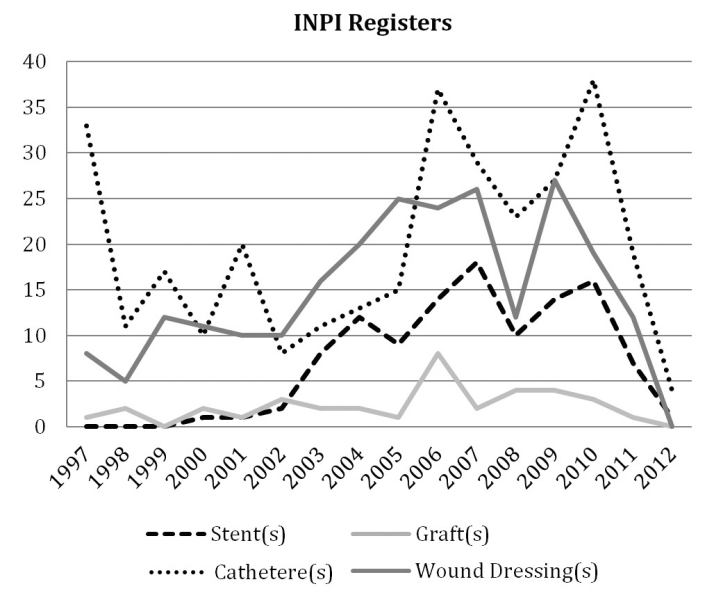

Figure 1. Number of patents registered by INPI over the course of the period studied.

Table 2. Number of products approved by ANVISA between 1997 and 2007.

\begin{tabular}{lcc}
\hline \multicolumn{1}{c}{ Search terms } & Total & Brazil* $^{*}$ \\
\hline Stent(s) & 184 & 8 \\
Graft(s) & 46 & 12 \\
Catheter(s) & 2793 & 135 \\
Wound dressing(s) & 410 & 113 \\
Total & 3433 & 268 \\
\hline
\end{tabular}

*Products manufactured in Brazil.

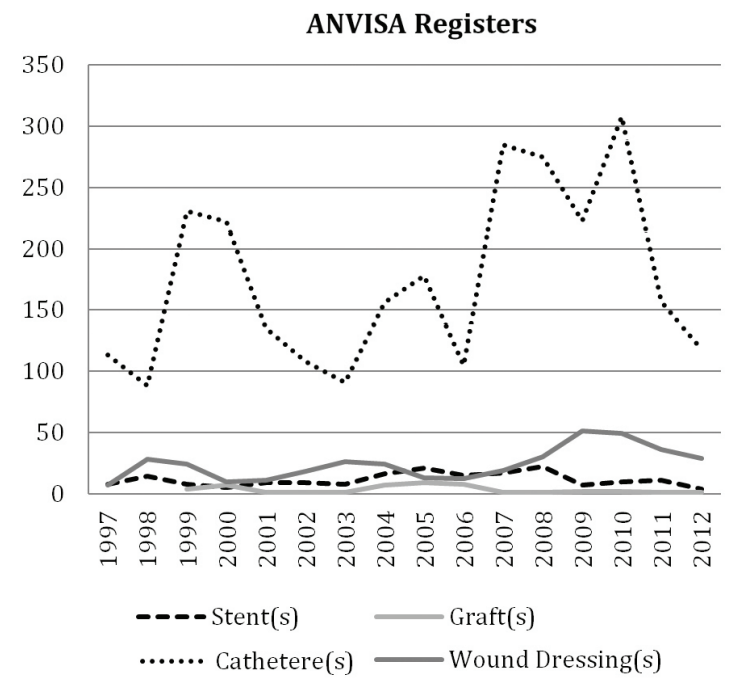

Figure 2. Number of products approved by ANVISA over the course of the period studied.

\section{DISCUSSION}

Although only a small number of firms are involved in the production and development of endovascular devices, this is a billion-dollar market, and the public health demand for new technology in the area have grown steadily over recent years. Although modern technology is often expensive, it may be financially worthwhile in the long term if it is able to reduce the recovery times and morbidity rates associated with endovascular procedures. ${ }^{1-4}$

The results show that a large number of patents were registered with INPI, suggesting that there have been significant technological advances in the area of endovascular surgery. ${ }^{7-11}$ However, the low number of products approved by ANVISA suggests that this technology has not been successfully applied to clinical practice. Over the course of the period studied, only 8 of the 113 stents for which INPI granted patents were approved for use by ANVISA.

Continued reliance on foreign technology may be responsible for the increased cost of technological advances in health care. Current debates regarding copyright law and the fact that patent registries are closely monitored in all developed countries have created a need for local alternatives to imported vascular and endovascular devices. The operative knowledge of physicians may play an important role in this process, which could eventually open up a promising new field for both health care and the economy. ${ }^{11}$

Given the potential economic and social repercussions of this type of technology, it becomes crucial to monitor developments in innovation and patent registries, and to make significant financial investments in the development of these materials. This would offer both a direct benefit for endovascular surgery patients and an indirect benefit to society, due to the increase in jobs and income associated with the establishment of new manufacturing industries. The need for local investment in such technology is particularly clear if we consider the costs associated with continuing reliance on imported material. In the USA, which does not rely so heavily on imported health care products, health spending is already expected to increase over the next 25 years, and it is predicted that it will eventually absorb $1 / 3$ of the country's GDP. If a similar pattern occurs in Brazil, and the additional cost of imported healthcare products is added to these estimates, the economic consequences could be extremely negative. ${ }^{4-12}$

There is an urgent need for the medical community to play a more active role in public policy in this 
area, investing in innovation and emphasizing the importance of managing and monitoring patent registries, with the objective of developing local alternatives to imported diagnostic and treatment procedures for angiology and vascular surgery, thereby contributing to patent output, which has become a new measure of wealth in the modern world.

\section{REFERENCES}

1. Regalado A. We need a Moore's Law for medicine. Business Report: A Cure for Health-Care Costs [revista eletrônica]. 2013 Set [citado 2014 jan 24]. http://www.technologyreview.com/news/518871/ we-need-a-moores-law-for-medicine/.

2. Skinner JS. The costly paradox of health-care technology. Business Report: A Cure for Health-Care Costs [revista eletrônica]. 2013 Set [citado 2014 jan 24]. http://www.technologyreview.com/ news/518876/the-costly-paradox-of-health-care-technology/.

3. Lee R, Davies G. Technology: the cure for rising healthcare costs? Views from the Marketplace: What is this? [revista eletrônica]. 2013 Set [citado 2014 jan 24]. http://www.technologyreview.com/ view/518946/technology-the-cure-for-rising-healthcare-costs/.

4. ResearchandMarkets. Researchandmarkets:Aorticendografts 2013 market research. Thomson Reuters. [revista eletrônica]. 2013 Jun [citado 2013 set 09]. http://www.reuters.com/article/2013/06/21/ research-and-markets-idUSnBw215299a+100+BSW20130621.

5. Research and Markets. Aortic stent grafts - global pipeline analysis, competitive landscape and market forecasts to 2017. MyPRGenie. [citado 2013 set 09]. http://www.myprgenie.com/ view-publication/aortic-stent-grafts-global-pipeline-analysiscompetitive-landscape-and-market-forecasts-to-2017.

6. Latin American aortic stent graft market to reach over $\$ 150$ million by 2015, according to millennium research group. Vascular Disease Management. 2010 Set [citado 2013 set 09] http://www. vasculardiseasemanagement.com/content/latin-american-aorticstent-graft-market-reach-over-150-million-2015-accordingmillennium-re.

7. Ascensão JO. Direito intelectual exclusivo e liberdade. Rev Esmafe. 2002;3:125-45. [citado 2013 set 09]. http://bdjur.stj.jus.br/dspace/ handle/2011/27320.

8. Grau-Kuntz K. O que é propriedade intelectual? Instituto Brasileiro de Propriedade Intelectual - IBPI. [citado 2013 set 09]. http://www.ibpibrasil.org/O-que-e-Propriedade-Intelectual.
9. Martins RO. Os núcleos de inovação tecnológica como estratégia das políticas de inovação do MCT (2004-2010). Latin American Journal of Business Mangement. 2012;3(2):226-47. [citado 2013 set 09]. http://www.lajbm.net/index.php/journal/article/view/95.

10. Matias-Pereira J. Política de ciência, tecnologia e inovação: uma avaliação da gestão do sistema de proteção à propriedade intelectual no Brasil. Independent Journal of a Management \& Production. 2011;2(2):44-75. [citado 2013 set 09]. http://www. ijmp.jor.br/index.php/ijmp/article/view/24/24.

11. Medeiros RL. Inovações tecnológicas e o processo de desenvolvimento econômico. Análise. 2007;18(1):51-63. [citado 2013 set 09]. http://revistaseletronicas.pucrs.br/ojs/index.php/ face/article/viewFile/358/261.

12. Pinheiro-Machado, R. Os indicadores de sucesso dos investimentos em C\&T no Brasil: positivo ou negativo? [dissertação]. Rio de Janeiro: Universidade Federal do Rio de Janeiro; 2004.

Correspondence
Sergio Quilici Belczak
Rua Cônego Eugênio Leite, 1126, ap. 153
CEP 05414-001 - São Paulo (SP), Brazi
Tel.: +55 (11) 983837803
E-mail: belczak@gmail.com

Author information

$\mathrm{HBO}$ - vascular surgeon and angiologist at Sociedade Brasileira de Angiologia e Cirurgia Vascular - Regional Minas (ANGIOVAS).

SQB - PhD in Surgical Techniques from the School of Medicine of Universidade de São Paulo (USP), is a professor of Vascular Surgery at the School of Medicine of Centro Universitário São Camilo, and a coordinator of the Residency Program in Vascular Surgery at Hospital Geral de Carapicuíba - OSS São Camilo. EFBO - vascular surgeon and angiologist at ANGIOVAS and Hospital Humanitas Unimed.

Author contributions Conception and design: SQB, HBO Analysis and interpretation: $\mathrm{SQB}, \mathrm{HBO}$ Data collection: SQB, $\mathrm{HBO}$ Writing the article: $\mathrm{SQB}, \mathrm{HBO}, \mathrm{EFBO}$ Critical revision of the article: $\mathrm{EFBO}, \mathrm{HBO}$ Final approval of the article*: SQB, HBO, EFBO Statistical analysis: $\mathrm{SQB}, \mathrm{HBO}$ Overall responsibility: SQB, $\mathrm{HBO}$

*All authors have read and approved of the final version of the article submitted to I Vasc Bras. 